\title{
The Influence of Dewey's Pedagogy in the Training of Basic Education Teachers of the Federal University of Amapá-Brazil
}

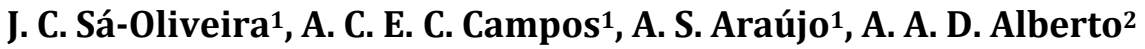 \\ ${ }^{1}$ Biological Sciences Course, Department of Biological Sciences of Health, Federal University of Amapá (UNIFAP), Campus Marco \\ Zero of Ecuador, Amapá, Brazil \\ ${ }^{2}$ Physical Education Course, Department of Education, Federal University of Ampá (UNIFAP), Campus Marco Zero of Ecuador, \\ Amapá, Brazil \\ Email:juliosa@unifap.br, ceccampos@unifap.br, andreaaraujo@unifap.br, alvaroduarte@unifap.br
}

How to cite this paper: Sá-Oliveira, J. C., Campos, A. C. E. C., Araújo, A. S., \& Alberto, A. A. D. (2017). The Influence of Dewey's Pedagogy in the Training of Basic Education Teachers of the Federal University of Amapá-Brazil. Creative Education, 8, 12131222.

https://doi.org/10.4236/ce.2017.88086

Received: May 12, 2017

Accepted: July 7, 2017

Published: July 10, 2017

Copyright $\odot 2017$ by authors and Scientific Research Publishing Inc. This work is licensed under the Creative Commons Attribution International License (CC BY 4.0).

http://creativecommons.org/licenses/by/4.0/

\begin{abstract}
The purpose of this study was to identify the influence of Dewey's pedagogy in the praxis of teacher-students in formation in the National Teacher Training Plan of Brazil, as well as to identify and reveal to these students the influences of this philosopher in the discipline theory and practice of teaching of Sciences. The methodological approach of the study was qualitative and quantitative, involving 65 student-teachers who were fulfilling this discipline. The research trajectory began with the use of questionnaires on world education theorists, explaining Dewey's theory to the evaluation of the plans developed by the student-teachers, observing indications pertinent to Dewey's pedagogy. The results showed that students did not know Dewey's educational ideas, although they used them at various points in their pedagogical activities. The influence of the ideas of this theorist in the discipline was evident in the development of the plans elaborated by the students, without excluding the influences of other important theoreticians of world education, as well as in their praxis, whether due to the compliance with the guidelines of the National Curricular Parameters or by the pedagogy intuition that each one has. It was also noticed that there is a gap in the formation of the student-teachers who participated in this study in disciplines that are responsible for presenting the main theorists of national and world education, especially the theoreticians whose ideas are implicit in the Brazilian National Curricular Parameters.
\end{abstract}

\section{Keywords}

Dewey's Philosophy, Education, Teacher Training, Brazil, PCN 


\section{Introduction}

The reality of Brazilian Education shows some visibly declining dynamics in terms of quality, with clear evidences of non-accompaniment of the $21^{\text {st }}$ century's technological revolution. This status quo affects all Brazilian society, especially those people of classes who are part of the base of the social pyramid. Many scholars, concerned about this situation, seek solutions to minimize this problem. Undoubtedly, the change in the Brazilian educational process is one way, if not the only one, to transform this reality (Villani \& Freitas, 1998; Abreu, 2000).

Official Brazilian data indicate that approximately $40 \%$ (200.816) of teachers in public schools teach classes in subjects in which they are not trained for, and 12.7\% do not even have higher education (MEC-Censo Escolar de 2015), which amplifies the problem of national education (MEC, 2015). In an attempt to minimize this situation, in 2009, the Ministry of Education implemented the National Plan for the Training of Basic Education Teachers (PARFOR). PARFOR is an emergency program designed to enable teachers in the public basic education network to access the higher education required by the National Education and Guidelines (LDB) Act (MEC, 2009).

One of the methodologies found to minimize the current situation of national education is the Pedagogy of Projects. The Pedagogy of Projects is old, and it is known that it is since the beginning of the twentieth century that it is discussed about its contribution to the teaching-learning process. This methodology arose in the early twentieth century with John Dewey and other representatives of the so-called "Active Pedagogy". At that time, the discussion was based on a conception that "education is a process of life and the school should represent the present life as real and vital to the student as he lives at home, in the neighborhood or on the patio" (Dewey, 2000).

Dewey was, and still is, an important name for education, either because of his strong influence on American education, since in the United States the entire educational structure is deeply influenced by Dewey's thinking (Di Giorgio, 1992), or in Brazil, in the period of the New School movement, especially in studies related to Psychology and History of Education, and his ideas are presented by Lourenço Filho and Anísio Teixeira (Cunha, 2002; Saviani, 2004, 2007).

In order to understand the conception of Education in Dewey, one must start from the idea that Education is a phenomenon created by and for society. For him, philosophy, pedagogy, and science were all based on the experimentation of the natural sciences, since he considered that scientific method is the only authentic means under our command to obtain an understanding of the real meaning of every day in the world in which we live, not excluding the theoretical foundation (Dewey, 1971; Silva \& Tavares, 2010).

Dewey wanted, through education, to build a better society, a better human being, one who would seek the truth, a democratic society, a progressive democracy. In this way, Dewey chose the school as a place to develop in the students the capacity to think and taught that the future is a construction that begins today, in the concreteness of our actions (Dewey, 1971; Pimenta, 2010; Silva 
\& Tavares, 2010).

In Brazil, the teaching of Natural Sciences has been practiced according to different educational proposals, which have been followed over the decades with theoretical elaborations that, in different ways, are expressed in classrooms. Many practices, even today, are based on the mere transmission of information, having as exclusive resource the textbook and its transcription on the blackboard; others already incorporate advances, produced in the last decades, on the teaching and learning process in general and on the teaching of Sciences, in particular the use of the experimental scientific method. However, research on the teaching of Natural Sciences has revealed what many teachers have already realized: that they should make use of experimentation, but noting that experimentation, without a broader investigative attitude, does not guarantee the learning of scientific knowledge. For this, relations with technology and other social and environmental issues must be considered (Brazil-PCN, 1997).

The discipline Theory and Practice of Sciences is a discipline that presents compulsory contents in the curriculum of the Brazilian Pedagogy courses. This course aims to provide teachers of initial grades with the necessary tools for the teaching of science related to those grades. It is a fact that the formation of these teachers constitutes a factor of great relevance in the framework of problems perceived in the teaching of Sciences. It is known that the teacher finishes the Teaching Degree course and the Degree in Pedagogy, usually without adequate training to teach Natural Sciences (Ducatti-Silva, 2005). In this sense, the teaching of Sciences for the first grades of Elementary School has some peculiarities when compared to the one of the subsequent grades. Its main characteristic is the fact that it is practiced by a polyvalent teacher, usually also responsible for teaching other disciplines (Ovigli \& Bertucci, 2009).

For Bizzo (2002), the formation of teachers of the initial grades trained in Pedagogy courses is hardly one of the priorities of the university system, where they have few opportunities in their education to deepen their scientific knowledge and teaching methodology Specific area. The difficulties faced by science teachers in the initial series with training in pedagogy stimulate some scholars in the area to reflect on these issues and, as a result, the need to rethink teacher education curricula (Longhini, 2008).

According to Echeverría, Mello, \& Duarte (2010), the quality of teacher education in Brazil, especially those in the initial grades, leaves no room for the appropriation of scientific knowledge and its implications in teaching practice, and indicate the need for a more elaborate discussion, permeated by epistemological aspects on the construction of knowledge, which are unnoticed in undergraduates and in the graduates.

In view of these questions, we justify that the purpose of this study was to perceive the gap in the training of PARFOR students at the Federal University of Amapá in relation to the pedagogical ideals underlying science education, especially those pertinent to the philosophy of Dewey, because it is understood that this theorist ideals are fundamental in the training of the teacher of this discip- 
line, whose theoretical approach of uniting teaching to reality and/or historical-social context of the learner, where everything learned is meaningful for students's everyday life and have significant affinities with the teaching of science.

As a guide for the study, two questions were elaborated: 1) Do PARFOR Pedagogy students know Dewey's ideas and recognize their pedagogical practices? 2) The activities developed in the discipline Theory and Practice of Sciences fit the pedagogical ideals of John Dewey?

Thus, the purpose of this study was to prospect the knowledge of PARFOR students about John Dewey's pedagogy, verifying the influences of this philosophy in training of science teachers in the discipline Theory and Practice of Sciences, aiming to contribute to the promotion and diffusion of this philosophy in Praxis of teachers in training, stimulating an education focused on the realities encountered by teachers in schools of communities where they work, which are, for the most part, precarious in structural and pedagogical aspects.

\section{Methods}

This study was developed during the years of 2015 and 2016 with classes of the Pedagogy Course of the National Plan of Basic Education Teachers of the Federal University of Amapá during the discipline Theory and Practice of Sciences, totaling 65 students. Most of these student-teachers develop their teaching practices in schools of distant communities, without adequate infrastructure and pedagogical dynamics, which compromises the teaching-learning process.

The course was developed in compliance with the legal constraints in Brazil's National Curriculum Parameters (NCP), from planning to class execution. The units of content worked were: 1) Epistemological Foundations of Natural Sciences. Interactions of sciences, technology, environment and society; History, Theoretical Currents and purpose of science teaching; 2) The scientific method and experimentation in science teaching; 3) Science and National Curriculum Parameters (NCPs): the science textbook and NCPs; 4) Theory and Practice as a methodology for Teaching Science in Early Childhood Education and in the Early Years of Elementary School: methods in science teaching: planning, assembly and execution; 5) The Science Laboratory; 6) Science Fair.

In the discipline's development, a prospective form was applied on the main theoreticians of world pedagogy, especially those that influenced and still influences Brazilian education, such as Piaget, Skinner, Vygotsky, John Dewey, Paulo Freire, Wallon, Pestalozzi, Montessori, Fröebel, Brunner, Anísio Teixeira, Perrenoud, Luckesi, Coll, Nóvoa and Toro. The instrument of exploration consisted of 2 questions: 1) Which of these Theorists of Education do you know or have heard? 2) Relate the theorist to his philosophy. In this study, there was no need to submit to the ethics committee, due to the absence of private information from the participants and their identification.

After the moment of prospecting on the theorists, an expositive lecture was given, using also other didactic resources such as texts and videos about the history and the main theoretical currents that influence the teaching of sciences in 
Brazil. Then a sequence of discussions on the content applied.

At the moment of discussion about the theoretical currents that underpin science education in Brazil, it was identified and emphasized what each pedagogical current represents in the national curricular parameters and the students-teachers were asked to reflect and indicate if their teaching practices were in line with the assumptions Contained in the PCNs and the respective theoretical currents. Subsequently, all the rest of the theoretical content pertinent to the discipline was given. After that, the course and class plans for the first, second, third and fourth cycles of elementary education were elaborated, according to the guidelines of the PCNs. The third and fourth cycles were worked even though they were not part of Elementary School I, due to the student-teacher's formation attending to the training continuum, not putting it in a tight situation. In addition, it is understood that it is of fundamental importance that the Pedagogue has some instrumentalization in the methodologies pertinent to the 3rd and 4th cycles so that they can guide and demand appropriate practices of those teachers who have formation for these cycles, such as Science Teachers, Biology, Chemistry, and Physics.

In order to verify the pedagogical influences of John Dewey in the lesson plans elaborated by the student-teachers, evaluations of the course and class plans were made, observing if they met the assumptions of Dewey's pedagogy through the five steps of learning that refer to the Scientific Experimental Method: 1) The Activity, 2) The Problem, 3) The data collection, 4) The Hypotheses and 5) The Experimentation.

In addition to the five methodological steps of Dewey, other pedagogical criteria were evaluated, according to the pedagogy of this theorist, such as the centralization of education, the behavioral introjection of the student, the compatibility with a social order, the required behavior regarding subordination or coordination and the performance of the student whether active or passive in the process of experimentation.

\section{Results and Discussion}

From the total of 65 students, it was verified that everyone knew Paulo Freire, Piaget, Vygotsky and Luckesi and their respective philosophies. Anísio Teixeira was known by $80 \%$ of the students, but only $20 \%$ knew his philosophy and contribution in the Brazilian Education. Some theorists such as Skinner $(n=9)$, Wallon ( $n=12)$, and Nóvoa $(n=16)$ were known to the students, but they did not know how to relate them to their respective educational theories, suggesting that students responded only not to demonstrate ignorance. The other theorists were not mentioned as known by the students, as well as their respective theories (Figure 1).

John Dewey was not mentioned by the students and even after answering the second prospective question, the student-teachers were not able to remember that they knew this theorist. This gap in knowledge was not elucidated by students since they did not remember that they had ever had contact with Dewey's name 


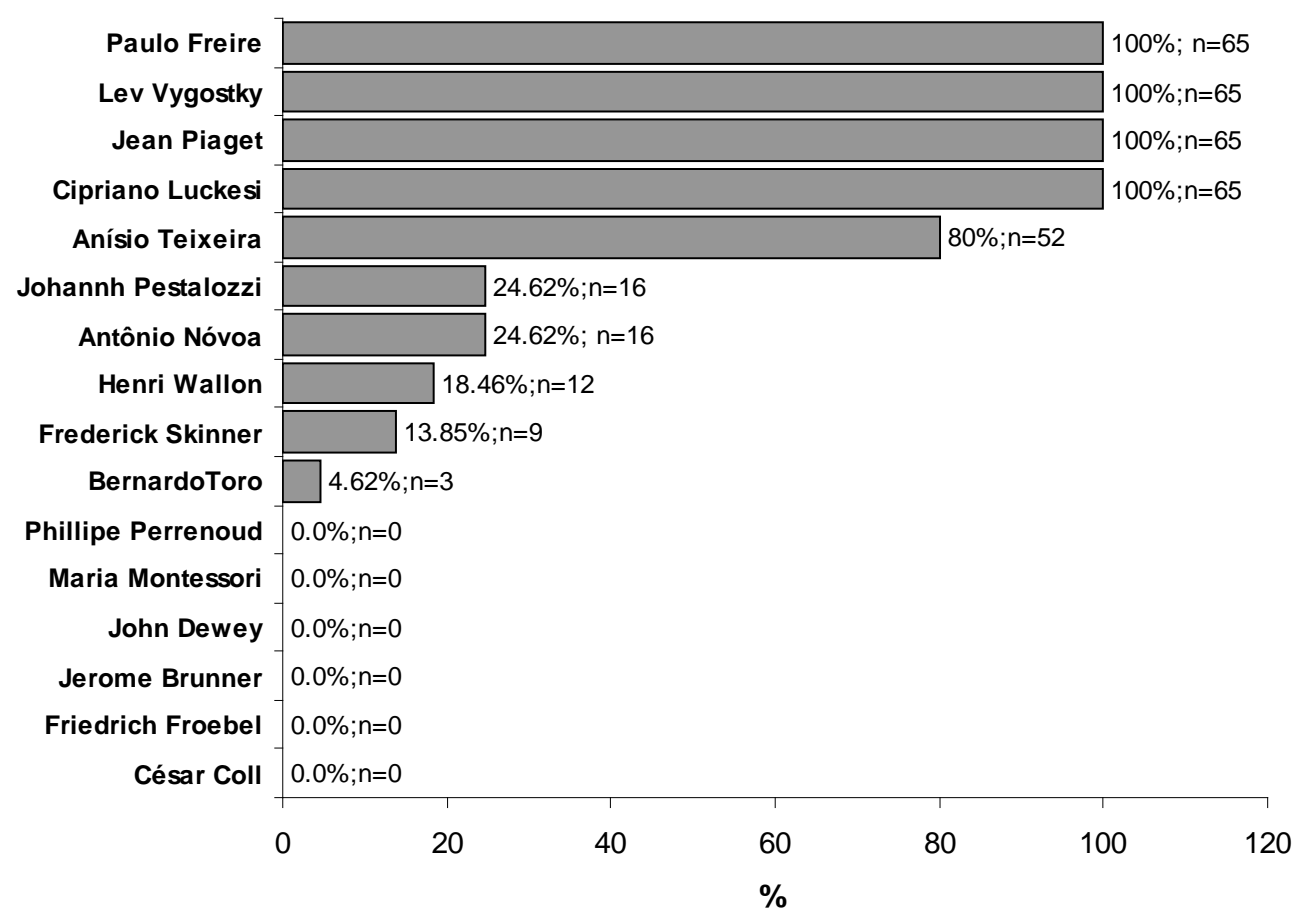

Figure 1. Theorists of education known by the PARFOR student-teachers.

and ideas. Perhaps this theorist has not been worked prominently in previous disciplines, such as theorists best known to students. This is a situation that may be related to the vast content taught in class in a compact period, which makes it difficult for students to establish knowledge.

John Dewey's philosophical and educational conception is regarded by historians as the most enduring and influential since the emergence of the notion of Active Learning. In the first half of the twentieth century, Dewey's ideas were disseminated in countries as distant and distinct as Japan and Mexico. In Brazil, his most prominent representative was Anísio Teixeira, a fact that causes more strangeness due to the absence of knowledge of Dewey by the students. Dewey's influence in Brazil was so important that the NCPs are full of directives of his philosophy (PCN, 1999).

In total, 2 course plans and 260 lesson plans were evaluated. The analysis of the plans indicated clear influences of Dewey's pedagogy, such as pedagogical centralization in the student and not in the teacher, orientation for the student to have self-control, coordination, and active character in the teaching-learning process (Table 1). It was not possible to gauge whether these student-teachers perform their classes following the planning with their students. However, developing their abilities while performing their activities during the Theory and Practice course suggests that the use of Dewey's methods in their classes often occurs.

As to the planning and performance in the execution of the same, developed according to the five steps recommended by Dewey, it was observed that not all student-teachers were successful, because despite properly planning the classes according to experimental scientific method, which underlies Dewey's pedagogy, 
not all have succeeded in developing what was planned. Sometimes because of lack of skill of the student-teacher and sometimes because of the quality of the material produced for the experimentation. Table 2 shows that almost all the requirements of Dewey's pedagogy were met, the only exception was in the development of experimentation that some students $(n=14 \% ; 20 \%)$ could not perform the experiments. In Dewey's pedagogy, the Experience is defined in a similar way to reflective thinking, which indicates that the research process, when effected properly, is an educational Experience.

Planning according to Dewey should always start from the experience and skills that the student acquired before arriving at school. The teacher should organize the activities for the students, taking into account the "growth in student experience, the expansion and organization of the subject under study" and concludes: "no experience will be educational if it does not tend to lead simultaneously to the knowledge of more facts, to entertain more ideas and the better and more organized arrangement of these facts and ideas" (Dewey, 1971).

Dewey's pedagogy also consisted of scientific research, taking the experiment-

Table 1. Centralization of the teaching-learning process in the student.

\begin{tabular}{ccc}
\hline Pedagogical dynamics & \multicolumn{1}{c}{ Attendance } \\
\cline { 2 - 3 } Teacher/School-centered & Plan I Plan II \\
Student centered & No & No \\
Introjects obedience to authority & Yes & Yes \\
Introjects self-control & No & No \\
Compatible with a social order & Yes & Yes \\
Founded in subordination & Yes & No \\
Founded in coordination & Yes & Yes \\
It reserves to the child a passive character & No & No \\
Put the child into active direct experimentation & Yes & Yes \\
\hline
\end{tabular}

Table 2. Adequacy of the development of lesson plans by PARFOR students, according to the five steps recommended by Dewey.

\begin{tabular}{|c|c|c|c|}
\hline Step & Fundamentals & $\begin{array}{c}\text { Plan } \\
\text { suitability }\end{array}$ & $\begin{array}{l}\text { Developed in } \\
\text { class }\end{array}$ \\
\hline 1) Activity & $\begin{array}{l}\text { The starting point of any learning in school, as well as in life, and that the school should reproduce } \\
\text { as well as possible, is an activity that is already being pursued; An activity that occurs } \\
\text { spontaneously and that corresponds to the interest of the learner, within a contentepertinente to } \\
\text { the cognition of each age. }\end{array}$ & Yes & Yes \\
\hline 2) Problem & $\begin{array}{l}\text { Every activity, when exercised, raises problems that hinder its continuity and/or development. This } \\
\text { is the origin of thought: it always comes from a problematic situation. The starting point of the } \\
\text { thought is the attempt of undertaking, of overcoming a problematic situation. }\end{array}$ & Yes & Yes \\
\hline 3) Data Collection & $\begin{array}{l}\text { Data collection: the teacher and the students should collect data that can help overcome the } \\
\text { problematic situation. }\end{array}$ & Yes & Yes \\
\hline 4) Hypothesis & $\begin{array}{l}\text { The data, once collected, will allow the formulation of one or more explanatory hypothesys of the } \\
\text { problem. }\end{array}$ & Yes & Yes \\
\hline 5) Experimentation & $\begin{array}{l}\text { The hypothesis must be tested to verify its validity. If it is valid, you can solve the problem and the } \\
\text { activity will continue until you encounter a new problem. }\end{array}$ & Yes & Yes/no \\
\hline
\end{tabular}


tal scientific method as one of the main paths of teaching and learning. For him, laboratory method is the lesson that all education must learn, it is the discovery of the conditions under which work can become intellectually fruitful and not merely a reproducer of external things (Dewey, 1979).

One of the conditioning factors of Dewey's education is problematization. According to Dewey, the use of problematization in the teaching-learning process is fundamental for meaningful knowledge to occur, since the learning would occur through previous experiences experienced by the student, where he would not only develop the technique but also the intellect and Morality in view of its integral development (Dewey, 1971).

For Patrício (1986) Dewey's educational program has an active dimension and is particularly experimental, since learning must be acquired through discovery in a temporal dynamic where the past interests as a lever to explore the present and build the future. In this same sense, Câmara \& Rocha (2009) says that it is noticeable in Dewey's philosophy that education is extremely practical, without ignoring the theory.

In the students' conception, it became clear that the discipline Theory and Practice of Science encourages students to understand that teaching is not reduced to a routine classroom occupation space, but it is an active space for scientific discovery on the most varied themes and which works as a starting point that enables students to reconstruct and analyze everything from their individual reality to the evolution of the universe. In addition, it was found that most student-teachers agreed that the teaching-learning process of the discipline Theory and Practice of Sciences was developed with the active participation of the students in the construction of their knowledge, which is in accordance with the Pedagogical ideals driven by Dewey, where the learner becomes an active educational agent of learning, with a curriculum vitae of concrete real-life activities (Dewey, 1979; Marques, 2001).

In the development of the discipline, it was notorious that teachers favor group work and cooperative learning, developing the capacity for communication and cooperation by cultivating attitudes of solidarity, showing that education is a process of life where one experiences and, at the same time, A social process, in accordance with Dewey's pedagogical principles, which affirm that education is a way for responsible citizenship, whose solutions to the problems of modern society require the development of the capacity for critical thinking (Dewey, 2007).

Another point highlighted by the students was the fact that the subject taught stimulates the teaching-learning process that relates and applies contents of other areas of knowledge with the teaching of science, establishing interdisciplinarity. Interdisciplinarity is in accordance with Dewey's (2002) pedagogy, where he affirms that innovative teaching implies conceiving the teaching-learning process as a process of construction in interaction with other fields of knowledge. A teaching in which the disciplines are related to the real world, with applications in everyday situations, not as abstract and useless. If the teacher can 
offer a teaching-learning process in a dynamic, attractive, and creative way, he has in his hands a valuable tool to develop in the student critical thinking, confidence in his/her cognitive potential and to use his/her competences with autonomy, sense of investigation and creation.

We understand that education in Brazil must consider the presence of new technologies that can and should be used to achieve quality education. For this, there must be profound changes in the formation and preparation of the teacher, with a new way of teaching-educating, proceeding, learning and changing (Abreu, 2000). For this change to take place, many interfaces need to be analyzed until a discussion of the contemporary education of Brazilian society is based, assuming that the current reality suffers with historical time, permeated by the political, economic and social course of this discussion (Prada, 2008).

\section{Conclusion}

In this study, it was evident that the student-teachers did not know Dewey and his pedagogical conceptions. However, most of them develop their praxis with influences from this theorist. This paradox is probably due to the fact that these student-teachers use the national curricular parameters as pedagogical guidance, whose theoretical conception was based, in part, on Dewey's ideas, mainly in the conception of the need to narrow the relation between theory and practice, since this thinker believed that the theoretical hypothesis only makes sense if inserted in the student's daily context. The discipline theory and Practice of Science Teaching taught during this study were designed to be developed according to Dewey's pedagogical principles, which were identified by the students in the closing of the discipline, proving the existence of the relation between the discipline taught and the ideas of the philosopher. All the activities planned and developed by the students were due to the integration work developed between the teacher trainer and the student teachers, which involved conceptions that reached the specific formation of science teaching and the pedagogical training, indicating that it is possible to develop this type of pedagogy, that of Dewey, in schools.

\section{Acknowledgements}

The authors thank all of the anonymous student participants in this study.

\section{References}

Abreu, K. (2000). O ensino on-line: Uma nova estratégia pedagógica. Revista SPEI, 1 , 18-20.

Alvarado Prada, L. E. (2008). Investigación colectiva: Aproximaciones teórico metodológicas. Estúdios Pedagógicos, 34.

http://www.scielo.cl/pdf/estped/v34n1/art09.pdf https://doi.org/10.4067/S0718-07052008000100009

Bizzo, N. (2002). Reflections upon a National Program Assessing Science Textbooks: What Is the Importance of Content in Science Education? IOSTE SYMPOSIUM, 10, 710-720. 
Brasil (1997). Parâmetros Curriculares Nacionais: Introdução (1 e 2 ciclos). Secretaria de Educação Fundamental, Brasília: MEC/SEF. 1v. http://portal.mec.gov.br/seb/arquivos/pdf/livro01.pdf

Câmara, C. A. O., \& Rocha, S. A. (2009). Pragmatismo Deweyano e Docência no Ensino Superior: Uma Reflexão Acerca da Identidade do Professor Bacharel. http://www.ie.ufmt.br/semiedu2009/gts/gt10/Comunicação

Cunha, M. V. (2002). John Dewey, a outra face da escola nova no Brasil. In Ghiraldelli, P. (Org.), O que é filosofia da Educação? (pp. 248-263). Rio de Janeiro: DP \& A Editora.

Dewey, J. (1971). Experiência e Educação. In Trad. Anísio Teixeira (pp. 13-41). São Paulo: Editora Nacional.

Dewey, J. (1979). Democracia e educação: Introdução à Filosofia da Educação (pp. 205-221). São Paulo: Nacional.

Dewey, J. (2002). A escola e a sociedade e A criança e o currículo (pp.16-21). Lisboa: Relógio D'Água.

Dewey, J. (2007). Democracia e Educação (pp. 11-15). Lisboa: Plátano.

Di Giorgio, C. (1992). Escola Nova (pp. 49-53). São Paulo: Ática.

Ducatti-Silva, K. C. (2005). A formação no curso de Pedagogia para o ensino de ciências das séries iniciais (222 p.). Dissertação (Mestrado em Educação) - Faculdade de Filosofia e Ciências, Marília: Universidade Estadual Paulista.

http://repositorio.unesp.br/bitstream/handle/11449/91234/silva_kcd_me_mar.pdf?sequ ence $=1$

Echeverría, A. R., Mello, I. C., \& Gauche, R. (2010). Livro didático: Análise e utilização no ensino de Química. In W. L. P. Santos, \& O. A. Maldaner (Eds.), Ensino de Química em Foco (pp. 263-286). Ijuí: Editora Unijuí.

Longhini, M. D. (2008). O conhecimento do conteúdo científico e a formação do professor das séries iniciais do ensino fundamental. Investigações em Ensino de Ciências, 13, 241-253.

http://www.if.ufrgs.br/ienci/artigos/Artigo_ID184/v13_n2_a2008.pdf

Marques, R. (2001). Professores, família e projecto educativo. Porto: Asa Editores.

Ovigli, D. F. B., \& Bertucci, M. C. S. O. (2009). Ensino de Ciências nas series iniciais e a formação do professor nas instituições públicas paulistas. Revista Brasileira de Educação Ciência e Tecnologia, 2, 88-104.

https://periodicos.utfpr.edu.br/rbect/article/view/460 https://doi.org/10.3895/s1982-873x2009000200007

Patrício, M. (1986). Anotações didáticas sobre a educação nova. Évora: Universidade de Évora.

Pimenta, S. G. O. (2010). Estágio na formação de Professores: Unidade teoria e prática (9th ed.)? São Paulo: Cortez.

Saviani, D. (2004). O legado educacional do século XX no Brasil. Campinas: Autores Associados.

Saviani, D. (2007). Pedagogia: O espaço da educação na universidade. Cadernos de Pesquisa, 37, 99-134. http://www.scielo.br/pdf/cp/v37n130/06.pdf

https://doi.org/10.1590/S0100-15742007000100006

Silva, L. P., \& Tavares, H. M. (2010). Pedagogia de Projetos: Inovação no Campo Educacional. Revista da Católica, 2, 236-245.

http://catolicaonline.com.br/revistadacatolica2/artigosv2n3/16-Pedagogia.pdf

Villani, A., \& Freitas, D. (1998). Análise de uma experiência didática na formação de professores de Ciências. Investigações em Ensino de Ciências, 3, 121-142. http://www.if.ufrgs.br/ienci/artigos/Artigo_ID41/v3_n2_a1998.pdf 
Submit or recommend next manuscript to SCIRP and we will provide best service for you:

Accepting pre-submission inquiries through Email, Facebook, LinkedIn, Twitter, etc. A wide selection of journals (inclusive of 9 subjects, more than 200 journals)

Providing 24-hour high-quality service

User-friendly online submission system

Fair and swift peer-review system

Efficient typesetting and proofreading procedure

Display of the result of downloads and visits, as well as the number of cited articles Maximum dissemination of your research work

Submit your manuscript at: http://papersubmission.scirp.org/

Or contact ce@scirp.org 